\title{
Remifentanil patient-controlled versus epidural analgesia on intrapartum maternal fever: a systematic review and meta- analysis
}

\author{
Guolin Lu*D, Wenshui Yao, Xiaofen Chen, Sujing Zhang and Min Zhou
}

\begin{abstract}
Background: Intravenous remifentanil patient-controlled analgesia (RPCA) is an alternative for epidural analgesia (EA) in labor pain relief. However, it remains unknown whether RPCA is superior to EA in decreasing the risk of intrapartum maternal fever during labor.

Methods: According to the Preferred Reporting Items for Systematic Reviews and Meta-Analyses (PRISMA) guidelines, a systematic review and meta-analysis was performed by searching PubMed, EMBASE and the Cochrane Central Register of Controlled Trials from inception to April 2019. All randomized controlled trials (RCTs) investigating the risk of intrapartum maternal fever with RPCA compared with EA alone or EA in combination with spinal analgesia during labor were included.

Results: A total of 825 studies were screened, and 6 RCTs including 3341 patients were identified. Compared with EA, RPCA was associated with a significantly lower incidence of intrapartum maternal fever (risk ratio [RR] 0.48, $P=$ $\left.0.02, P^{2}=49 \%\right)$ during labor analgesia. After excluding 2 trials via the heterogeneity analysis, there was no difference in the incidence of intrapartum fever between patients receiving RPCA and those receiving EA. Satisfaction with pain relief during labor was lower in the RPCA group than that in the EA group $(-10.6[13.87,-7.44], P<0.00001$, $P=0 \%)$. The incidence of respiratory depression was significantly greater in the RPCA group than that in the EA group (risk ratio $2.86[1.65,4.96], P=0.0002, P^{2}=58 \%$ ). The incidence of Apgar scores $<7$ at 5 min in the RPCA group was equivalent to that in the EA group.
\end{abstract}

Conclusion: There is no solid evidence to illustrate that the incidence of intrapartum maternal fever is lower in patients receiving intravenous RPCA than in patients receiving EA.

Keywords: Remifentanil, Epidural, Fever, Labor, Pain

\section{Background}

Intrapartum fever in women receiving epidural analgesia (EA) is associated with a higher risk of cesarean delivery and assisted ventilation in neonates, neonatal hypotonia, unnecessary neonatal antibiotic treatment, and even early-onset seizures [1-4]. Intrapartum fever is referred to as maternal temperature not less than $38^{\circ} \mathrm{C}\left(100.4^{\circ} \mathrm{F}\right)$ during labor [5]. Epidural-related maternal fever (ERMF)

\footnotetext{
* Correspondence: drguolinlu@hotmail.com

Department of Anesthesiology, Fujian Maternity and Child Health Hospital, Affiliated Hospital of Fujian Medical University, 18 Daoshan Road, Fuzhou 350001, Fujian Province, China
}

has been reported in approximately $20 \%$ of women receiving EA for labor pain relief [5]. A prospective cohort study published that a rise in maternal temperature is associated with a higher body mass index value and longer time from rupture of membranes to delivery and that EA had no this effect on maternal temperature [6].

However, accumulating evidence has confirmed that EA is independently responsible for maternal temperature elevation during labor $[1,5,7-9]$. During epidural labor analgesia, a regular intermittent bolus produced an incidence of ERMF equivalent to that of continuous infusion [10]. Antibiotic prophylaxis has been demonstrated to be ineffective 
for ERMF [9]. It has been reported that higher levels of the maternal pyrogenic cytokine, interleukin (IL)-6 were measured in intrapartum patients receiving EA than in other patients [5]. Bupivacaine has been found to impair the ability of anti-pyrogenic IL-1rd to promote ERMF during labor [7]. Multiple inflammatory signaling pathways are activated by ropivacaine in human umbilical vein endothelial cells and placental trophoblasts as a result of ERMF [11]. Obviously, ERMF is likely to be associated with noninfectious inflammation.

Remifentanil has been found to ameliorate the inflammatory response induced by surgical stress in rats [12]. It is likely that the anti-inflammatory effect of remifentanil may have bring a potential benefit for intrapartum maternal fever. Remifentanil is commonly used in the obstetric analgesia. Recently, a multicenter, randomized controlled trial (RCT) concluded that intravenous remifentanil patient-controlled analgesia (RPCA) is more efficient than intramuscular pethidine for pain relief during labor [13]. Although RPCA is inferior to EA regarding its efficacy in attenuating labor pain [14, 15], Douma et al., published that pyrexia developed to a lower degree in parturient women receiving RPCA compared with patients receiving EA [16]. A similar tendency has also been observed in a randomized multicenter equivalence trial [14]. Inconsistent with these findings, another trial has provided the evidence that there is no difference in the intrapartum fever between patients receiving RPCA and those receiving EA [17]. It still remains controversial whether RPCA is superior to EA in decreasing the rate of the intrapartum maternal hyperthermia.

Intravenous RPCA is shown to be an alternative to pain relief during labor [18]. Currently, there is no review aimed at assessing the risk of an intrapartum maternal fever between patients receiving RPCA and those receiving EA. We hypothesized that the incidence of intrapartum fever in patients receiving RPCA is lower than that in those receiving EA. To test this hypothesis, we performed a meta-analysis of RCTs evaluating the risk of intrapartum fever and the efficacy and safety of intravenous RPCA in women compared with EA in women.

\section{Methods}

\section{Search strategy}

A systematic review was conducted in line with the Preferred Reporting Items for Systematic Reviews and MetaAnalyses (PRISMA) [19] guidelines before the study was designed. The study protocol was registered prospectively in the International Prospective Register Of Systematic Reviews (PROSPERO). (https://www.crd.york.ac.uk/PROSPERO/\#myprospero ID = CRD42019135235). A systematic literature search was carried out in the PubMed, EMBASE, and the Cochrane Central Register of Controlled Trials for publications published before April 30, 2019. No language limitations were applied. All were restricted to title and abstract. We also queried coauthors about nonpublished studies and manually scanned reference lists of relevant reviews, trials, and reports in case of unknown sample size. Otherwise, we did not contact authors for further information since we strived to decrease reporting bias. The search terms were "analgesia," "analgesic," "pain," "intrapartum," "maternal," "maternity," "labor," "parturition," "delivery," "parturient," "fever," "heat," "hyperthermia," "temperature," "pyrexia," and "remifentanil" (examples of the online search strategy are shown in the supplementary text).

\section{Identification of eligible studies}

Inclusion criteria included English articles regarding RCTs, studies comparing intravenous RPCA with EA during labor, an epidural infusion of at least $4 \mathrm{~h}$, and intrapartum fever defined as a maternal temperature $\geq$ $38^{\circ} \mathrm{C}$. All women who were in labor with an American Society of Anesthesiology class I or II status, a planned vaginal delivery, and a gestation of at least 32 weeks of gestation, and who were aged not less than 18, were considered to be eligible for inclusion. Studies were eligible for inclusion if they reported one or more of the following predetermined outcomes: our primary outcome was intrapartum maternal fever (temperature $\geq$ $38^{\circ} \mathrm{C}$ ) after labor analgesia; secondary outcomes included the satisfaction with regard to pain relief during labor expressed as the area under the curve (AUC), respiratory depression, and the Apgar score at $5 \mathrm{~min}$.

Studies in line with any of the following criteria were excluded: nonhuman studies, articles in other than English, review articles, conference abstracts, letters, editorial articles, irrelevant topics, nonrandomized trials, incorrect comparisons, or the primary outcomes not reported. Studies were excluded if they enrolled pregnant women who had a body mass index $\geq 40 \mathrm{~kg} / \mathrm{m}^{2}$, severe preeclampsia, or an initial maternal temperature $\geq 38^{\circ} \mathrm{C}$, or who used antibiotics during labor.

\section{Assessment of methodological quality}

Two authors, Wenshui Yao, and Xiaofen Chen, were responsible for assessing the methodological quality of the included studies, according to the Cochrane Collaboration tool. Studies were screened on random sequence generation and allocation concealment, blinding of participants and personnel, blinding of outcome assessment, incomplete outcome data, selective reporting, and other bias based on the sample size calculation. The studies were ranked with a low, high, or unclear risk of bias.

\section{Data extraction}

Two reviewers (Lingshan Ye and Wenshui Yao) used a predefined form to independently extract data regarding study characteristics (time period, country, maternal age, 
gestational age, and labor analgesia regimen), participant number (randomized, dropped-out, crossed-over, actually received pain relief), and the definition and measured duration of intrapartum maternal fever.

\section{Data synthesis and analysis}

All analyses were carried out using Review Manager (RevMan version 5.3.5, Copenhagen: The Nordic Cochrane Center, The Cochrane Collaboration, 2014). We calculated risk ratios and $95 \%$ confidence intervals using the random effects Mantel-Haenszel model for dichotomous outcomes. For continuous outcomes, we calculated weighted mean differences and $95 \%$ confidence intervals. The significance level was set as $P<0.05$. $\mathrm{I}^{2}$ was used to assess heterogeneity. When the $\mathrm{I}^{2}$ value was larger than $50 \%(\geq 50 \%)$, a sensitivity analysis was conducted to explore the influence of measure duration and group allocation. Publication bias was examined using a funnel plot.

\section{Results}

\section{Study identification and characteristics}

The flow of the study selection is shown in Fig. 1. The systematic search yielded a total of 825 studies. After removing duplicates, the title and abstract of 513 studies were screened. Subsequently, 196 full articles were evaluated for eligibility. At the end of the selection, six RCTs enrolling 3341 participants undergoing delivery were included in the meta-analysis [14-17, 20, 21] (major characteristics reported in Table 1). We excluded 1 multicenter trial only comparing intravenous remifentanil with intramuscular pethidine, 39 trials not reporting intrapartum maternal temperature, and 29 trials enrolling participants without epidural labor analgesia.

All included RCTs compared RPCA with EA conducted by continuous infusion. As shown in Table 2, 2344 participants were actually received pain relief during labor. Three trials compared intravenous RPCA with EA $[14,15$,

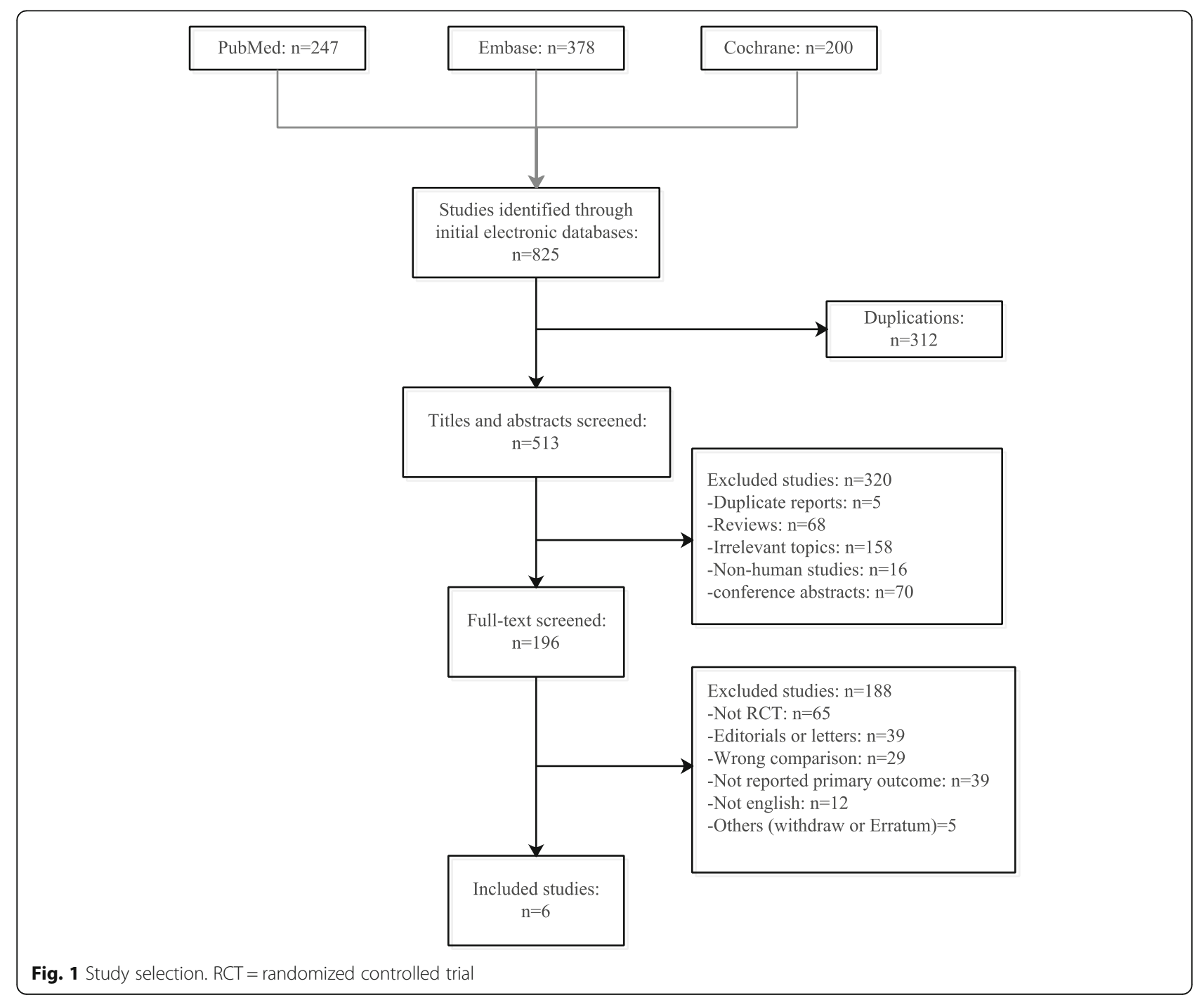


Table 1 The characteristics of included studies

\begin{tabular}{|c|c|c|c|c|c|}
\hline Study & Country & $\begin{array}{l}\text { Maternal age (years) } \\
\text { mean (SD) }\end{array}$ & $\begin{array}{l}\text { gestational age (weeks) } \\
\text { mean (SD) }\end{array}$ & RPCA & EA \\
\hline $\begin{array}{l}\text { Logtenberg } \\
2017[15]\end{array}$ & Nertherlands & $\begin{array}{l}\text { RPCA: } 31.7(3.9) \\
\text { EA: } 31.8(4.2)\end{array}$ & $\begin{array}{l}\text { RPCA:36.1 (34.3-37.6) } \\
\text { EA:36.1 (33.9-37.7) }\end{array}$ & $\begin{array}{l}\text { boluses:30 } \mu \mathrm{g}(20 \\
\text { to } 40) \\
\text { lockout time:3 } \\
\text { min } \\
\text { no background } \\
\text { infusion }\end{array}$ & $\begin{array}{l}\text { Loading dose: } 25 \mathrm{mg} \\
\text { ropivacaine } 0.2 \% \\
\text { Cl: } 0.1 \% \text { ropivacaine plus } \\
\text { sufentanil } 0.5 \mu \mathrm{g} / \mathrm{ml}\end{array}$ \\
\hline $\begin{array}{l}\text { Freeman } 2015 \\
{[14]}\end{array}$ & Nertherlands & $\begin{array}{l}\text { RPCA:31.5 (5.1) } \\
\text { EA:31.7 (4.8) }\end{array}$ & $\begin{array}{l}\text { RPCA: } 37.8(35.5-39.2) \\
\text { EA:37.1 (35.3-39.0) }\end{array}$ & $\begin{array}{l}\text { boluses: } 30 \mu g(20 \\
\text { to } 40) \\
\text { lockout time: } 3 \\
\text { min } \\
\text { no background } \\
\text { infusion }\end{array}$ & $\begin{array}{l}\text { epidural analgesia: ropivacaine } \\
\text { or bupivacaine, or levobupivacaine } \\
\text { plus sufentanil }\end{array}$ \\
\hline $\begin{array}{l}\text { Douma } 2015 \\
\text { [16] }\end{array}$ & Nertherlands & $\begin{array}{l}\text { RPCA:32 (4.8) } \\
\text { EA:31 (5.6) } \\
\text { Con:33 (4.5) }\end{array}$ & $\begin{array}{l}\text { RPCA:39 } \\
\text { EA:40 } \\
\text { Con:40 }\end{array}$ & $\begin{array}{l}\text { bolus: } 40 \mu \mathrm{g} \\
\text { lockout time: } 2 \\
\text { min } \\
\text { no background } \\
\text { infusion }\end{array}$ & $\begin{array}{l}\text { loading dose: } 25 \mathrm{mg}(12.5 \mathrm{ml} \\
\text { ropivacaine } 0.2 \%) \\
\text { Cl: ropivacaine } 0.1 \% \text { plus sufentanil } \\
0.5 \mu \mathrm{g} / \mathrm{ml}\end{array}$ \\
\hline Stocki 2014 [17] & Israel & $\begin{array}{l}\text { RPCA:31(5) } \\
\text { EA:30 (6) }\end{array}$ & not reported & $\begin{array}{l}\text { bolus: } 20-60 \mu g \\
\text { lockout time: } 2 \\
\text { min } \\
\text { no background } \\
\text { infusion }\end{array}$ & $\begin{array}{l}\text { loading dose: } 0.1 \% \text { bupivacaine } \\
\text { with } 50 \mu \mathrm{g} \text { fentanyl } 15 \mathrm{ml} \\
\text { Cl: } 0.1 \% \text { bupivacaine with } 2 \mu \mathrm{g} / \mathrm{ml} \\
\text { fentanyl, PCA } 10 \mathrm{ml} \\
\text { lockout interval: } 20 \mathrm{~min}\end{array}$ \\
\hline Ismail 2012 [21] & china & $\begin{array}{l}\text { RPCA:28.35(5.54) } \\
\text { EA:28.6 (5.49) } \\
\text { CSEA:28.8 (5.50) }\end{array}$ & $\begin{array}{l}\text { RPCA:39.2 (1.1) } \\
\text { EA:39.0 (1.3) } \\
\text { CSEA:39.1 (1.2) }\end{array}$ & $\begin{array}{l}\text { bolus: } 25 \mu \mathrm{g} \\
\text { Cl:0.1-0.9 } \mu \mathrm{g} / \mathrm{kg} \\
\text { lockout time: } 1 \\
\text { min }\end{array}$ & $\begin{array}{l}\text { loading dose: } 8 \mathrm{ml} 0.125 \% \text { levobupivacaine } \\
\text { with } 2 \mu \mathrm{g} / \mathrm{mL} \text { fentanyl } \\
\mathrm{Cl}: 0.125 \% \text { levobupivacaine with } 2 \\
\mu \mathrm{g} / \mathrm{ml} \text { fentanyl, } 8 \mathrm{ml} / \mathrm{h} \\
\text { CSEA: } 2 \mathrm{mg} \text { levobupivacaine and } 15 \\
\mu \mathrm{g} \text { fentanyl (total } 2 \mathrm{ml} \text { ) }\end{array}$ \\
\hline Evron 2008 [20] & Israel & $\begin{array}{l}\text { RPCA: } 29(7) \\
\text { EA: } 28(5) \\
\text { RPCA+EA: } 27 \text { (5) } \\
\text { RPCA+acetaminophen: } \\
27 \text { (4) }\end{array}$ & not reported & $\begin{array}{l}\text { bolus: } 20 \mu \mathrm{g} \\
\text { lockout time: } 3 \\
\text { min } \\
\text { no background } \\
\text { infusion }\end{array}$ & $\begin{array}{l}\text { loading dose: } 5-10 \mathrm{ml} \text { of } 0.2 \% \\
\text { ropivacaine } \\
\text { Cl: } 10 \mathrm{mg} / \mathrm{h} \text { 0.2\% ropivacaine } \\
\text { PCEA: } 10 \mathrm{mg} 0.2 \% \text { ropivacaine } \\
\text { lockout: } 20 \mathrm{~min}\end{array}$ \\
\hline
\end{tabular}

$R P C A$ remifentanil patient-controlled analgesia, EA epidural analgesia, CSEA combined spinal with epidural analgesia, Con control, $C l$ continuous infusion.

Table 2 The participants and outcome of included study.

\begin{tabular}{|c|c|c|c|c|c|c|c|c|}
\hline Study & $\begin{array}{l}\text { randomised } \\
\text { participants }\end{array}$ & $\begin{array}{l}\text { drop- } \\
\text { out }\end{array}$ & $\begin{array}{l}\text { cross- } \\
\text { over }\end{array}$ & $\begin{array}{l}\text { actually received } \\
\text { pain relief }\end{array}$ & $\begin{array}{l}\text { intenstion-to- } \\
\text { treat }\end{array}$ & $\begin{array}{l}\text { Intrapartum fever } \\
\text { definition }\end{array}$ & $\begin{array}{l}\text { temperature } \\
\text { mode }\end{array}$ & $\begin{array}{l}\text { measure } \\
\text { duration }\end{array}$ \\
\hline $\begin{array}{l}\text { Logtenberg } \\
2017 \text { [15] }\end{array}$ & 418 & $\begin{array}{l}\text { RPCA: } \\
98 \\
\text { EA:105 }\end{array}$ & $\begin{array}{l}\text { RPCA: } \\
11 \\
\text { EA:14 }\end{array}$ & $\begin{array}{l}\text { RPCA:94 } \\
\text { EA:76 }\end{array}$ & yes & $>38^{\circ} \mathrm{C}$ & not reported & $\begin{array}{l}\text { during } \\
\text { analgesia }\end{array}$ \\
\hline $\begin{array}{l}\text { Freeman } 2015 \\
\text { [14] }\end{array}$ & 1414 & $\begin{array}{l}\text { RPCA: } \\
22 \\
\text { EA:31 }\end{array}$ & $\begin{array}{l}\text { RPCA: } \\
53 \\
\text { EA:33 }\end{array}$ & $\begin{array}{l}\text { RPCA:447 } \\
\text { EA:347 }\end{array}$ & yes & $>38^{\circ} \mathrm{C}$ & not reported & during labor \\
\hline $\begin{array}{l}\text { Douma } 2015 \\
\text { [16] }\end{array}$ & 116 & & $\begin{array}{l}\text { RPCA:8 } \\
\text { EA:1 }\end{array}$ & & no & $\geq 38^{\circ} \mathrm{C}$ & $\begin{array}{l}\text { tympanic } \\
\text { membrance }\end{array}$ & within $4 \mathrm{~h}$ \\
\hline Stocki 2014 [17] & 40 & $\begin{array}{l}\text { RPCA: } \\
1 \\
\text { EA:0 }\end{array}$ & $\begin{array}{l}\text { RPCA:3 } \\
\text { EA:1 }\end{array}$ & $\begin{array}{l}\text { RPCA:19 } \\
\text { EA:20 }\end{array}$ & no & not reported & not reported & within $1 \mathrm{~h}$ \\
\hline Ismail 2012 [21] & 1140 & $\begin{array}{l}\text { RPCA: } \\
0 \\
\text { EA:0 }\end{array}$ & $\begin{array}{l}\text { not } \\
\text { report }\end{array}$ & $\begin{array}{l}\text { RPCA:380 } \\
\text { EA:380 } \\
\text { CSEA:380 }\end{array}$ & no & not reported & oral temperature & within $1 \mathrm{~h}$ \\
\hline Evron 2008 [20] & 213 & 12 & $\begin{array}{l}\text { not } \\
\text { report }\end{array}$ & 201 & no & $\geq 38^{\circ} \mathrm{C}$ & oral temperature & within $6 \mathrm{~h}$ \\
\hline
\end{tabular}


17]. One trial had two control groups including an EA group and a no analgesia group [16]. One trial assigned EA and combined spinal-epidural analgesia as the control groups [21]. The trial published by Evron et al. compared RPCA with three control groups including EA, RPCA plus EA, and RPCA plus acetaminophen [20].

The characteristics of the included studies are reported in Table 1. There was no difference between RPCA and EA in maternal age and pregnant weeks. Six inclusion trials reported the randomized allocation, concealment regimen and sample size calculation. The participants and outcomes of the included studies are described in Table 2. Five trials were funded by nonprofit organizations $[14,16,17,20,21]$, while no pharmaceutical company funded any trial.

The overall quality was good for all included studies. The risk of bias summary for each study is reported in Fig. 2, and the risk of bias graph for the individual trials were summarized in Fig. S1. The publications were found to have no bias according to the analysis of funnel plots in Fig. S2.

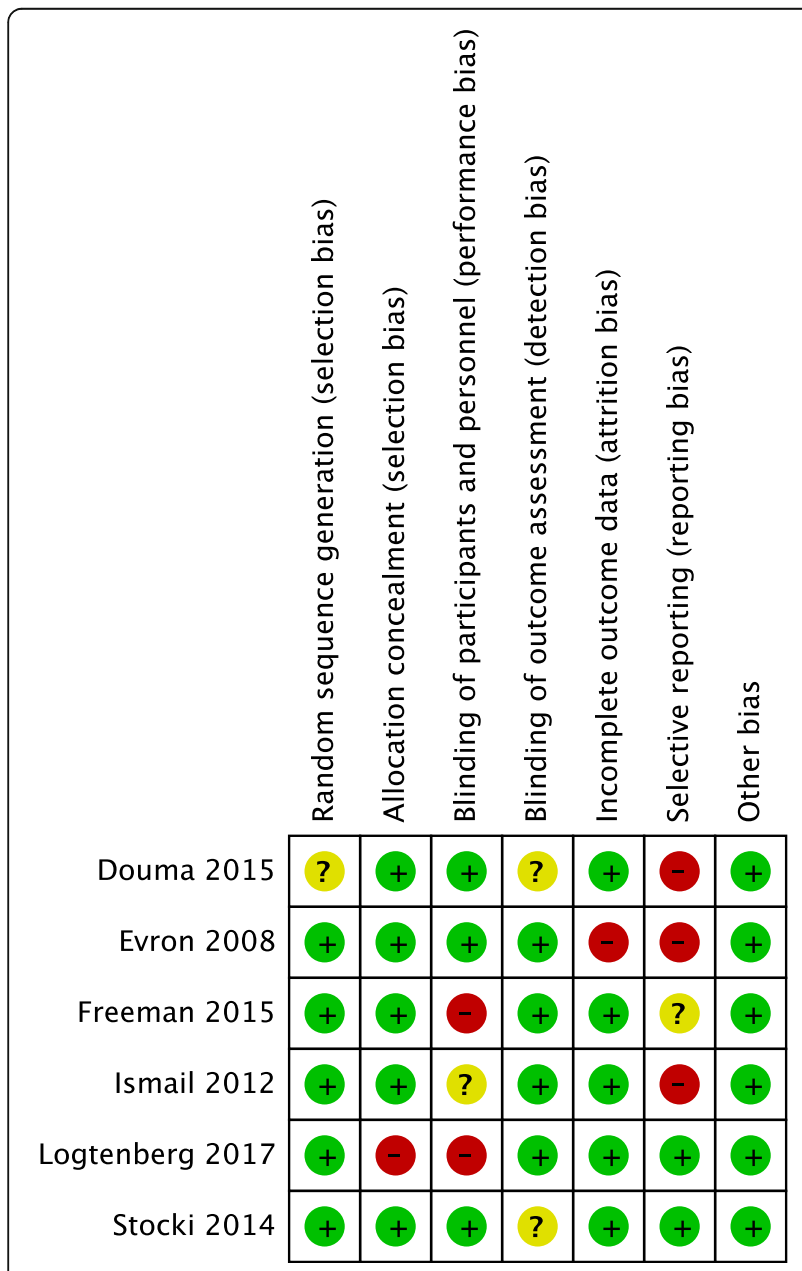

Fig. 2 Risk of bias summary
Primary endpoint: the number of intrapartum maternal fevers RPCA versus $E A$

Overall, six trials compared intravenous RPCA $(n=$ 1035) with EA $(n=922)$ for labor pain relief, as shown in Fig. 3a [14-17, 20, 21]. The incidence of maternal fever with intravenous RPCA (50/1035) was lower than that with EA (86/922) during labor. The risk of intrapartum maternal fever with RPCA declined to $52 \%$ of that with EA (relative ratio 0.48, 95\% confidence interval: $0.26-0.89, P=0.02, \mathrm{I}^{2}=47 \%$ ) within 1 or more hours. It drew our attention that the fever number of participants with fever in both the RPCA and EA groups remained at zero within $1 \mathrm{~h}$ of receiving pain relief. Thus, we excluded one trial by Ismail et al. [21] and another by Stocki et al. [17] to conduct the subgroup analysis. Compared with the risk of intrapartum maternal fever with EA, that with RPCA was $48 \%$ (relative ratio $0.48,95 \%$ confidence interval: $0.26-0.90, \quad P=0.02, \quad \mathrm{I}^{2}=49 \%$ ) (Fig. 3b). Excluding two trials $[16,20]$ that not only investigated EA but also other analgesia modes other than RPCA increased heterogeneity from 49 to 63\% (Fig. 3c). Those two trials $[14,15]$ remained to be assessed as having a high risk of bias for blinding (Fig. 2). Two studies $(n=964)$ demonstrated that there was no significant difference between RPCA and EA during the entire labor stage (relative ratio $0.69,95 \%$ confidence interval: 0.29 1.61, $\left.P=0.39 . \mathrm{I}^{2}=63 \%\right)[14,15]$ (Fig. 3c).

\section{Secondary endpoints}

Satisfaction with pain relief during labor

Satisfaction with pain relief during labor is usually measured using a visual analog scale ranging from 0 to 100 $\mathrm{mm}$. The AUC was a summary measure that integrated serial visual analog scale assessments, which represented satisfaction with pain relief at least two different time points. A higher AUC means a higher satisfaction with pain relief. Two trials $(n=954)$ compared RPCA with EA with respect to satisfaction with pain relief during labor analgesia using the AUC [14, 15]. The intention-to-treat was used to analyze the AUC in these two studies. As shown in Fig. 4a, RPCA was inferior to EA (- 10.6 [13.87, $\left.-7.44], P<0.00001, I^{2}=0 \%\right)$.

\section{Respiratory depression}

Respiratory depression is thought to be the main complication related to remifentanil during labor analgesia. Three studies reported respiratory depression with pain relief during labor [14-16]. Compared with respiratory depression developed with EA, the incidence of respiratory depression significantly increased with RPCA (risk ratio $2.86[1.65,4.96], P=0.0002, I^{2}=58 \%$ ) (Fig. 4 b). 


\begin{tabular}{|c|c|c|c|c|c|c|c|c|c|c|c|}
\hline \multicolumn{2}{|c|}{$\begin{array}{c}\text { A intrapartum mater } \\
\text { Study or Subgroup }\end{array}$} & \multicolumn{2}{|c|}{ Remifentanil } & \multicolumn{2}{|c|}{ Epidural } & Weight & $\begin{array}{c}\text { Risk Ratio } \\
\text { M-H, Random, } 95 \% \mathrm{Cl}\end{array}$ & \multicolumn{4}{|c|}{$\begin{array}{c}\text { Risk Ratio } \\
\text { M-H, Random, } 95 \% \mathrm{Cl}\end{array}$} \\
\hline & Douma 2015 & 5 & 49 & 18 & 49 & $25.0 \%$ & $0.28[0.11,0.69]$ & & $=$ & & \\
\hline & Evron 2008 & 1 & 44 & 7 & 50 & $7.7 \%$ & $0.16[0.02,1.27]$ & & & & \\
\hline & Freeman 2015 & 35 & 447 & 55 & 347 & $44.6 \%$ & $0.49[0.33,0.74]$ & & & & \\
\hline & Ismail 2012 & 0 & 380 & 0 & 380 & & Not estimable & & & & \\
\hline & Logtenberg 2017 & 9 & 96 & 6 & 76 & $22.7 \%$ & $1.19[0.44,3.19]$ & & & $t=-$ & \\
\hline & Stocki 2014 & 0 & 19 & 0 & 20 & & Not estimable & & & & \\
\hline & Total $(95 \% \mathrm{Cl})$ & & 1035 & & 922 & $100.0 \%$ & $0.48[0.26,0.89]$ & & & & \\
\hline & Total events & 50 & & 86 & & & & & & & \\
\hline & $\begin{array}{l}\text { Heterogeneity: } \operatorname{Tau}^{2}= \\
\text { Test for overall effect }\end{array}$ & $\begin{array}{l}=0.18 ; \mathrm{Chi} \\
: \mathrm{Z}=2.35\end{array}$ & $\begin{array}{l}i^{2}=5.71 \\
(P=0.0\end{array}$ & 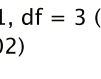 & $(P=0$. & $.13) ; I^{2}=$ & $47 \%$ & 0.01 & $\begin{array}{c}0.1 \\
\text { Favours [Remifentanil] }\end{array}$ & 1 Favours [Epidural] & 100 \\
\hline & intrapartum mate & rnal feve & er after & 1 hour & & & & & & & \\
\hline & & Remifen & ntanil & Epidur & & & Risk Ratio & & & Ratio & \\
\hline \multirow[t]{8}{*}{ B } & Study or Subgroup & Events & Total & Events & Total & Weight & $\mathrm{M}-\mathrm{H}, \mathrm{Random}, 95 \% \mathrm{Cl}$ & & M-H, Ranc & dom, $95 \% \mathrm{Cl}$ & \\
\hline & Douma 2015 & 5 & 49 & 18 & 49 & $25.2 \%$ & $0.28[0.11,0.69]$ & & $\longrightarrow-$ & & \\
\hline & Evron 2008 & 1 & 44 & 7 & 50 & $7.9 \%$ & $0.16[0.02,1.27]$ & & & - & \\
\hline & Freeman 2015 & 35 & 447 & 55 & 347 & $44.1 \%$ & $0.49[0.33,0.74]$ & & $\rightarrow-$ & & \\
\hline & Logtenberg 2017 & 9 & 94 & 6 & 76 & $22.9 \%$ & $1.21[0.45,3.26]$ & & & - & \\
\hline & Total $(95 \% \mathrm{Cl})$ & & 634 & & 522 & $100.0 \%$ & $0.48[0.26,0.90]$ & & & & \\
\hline & Total events & 50 & & 86 & & & & & & & \\
\hline & $\begin{array}{l}\text { Heterogeneity: } \mathrm{Tau}^{2} \\
\text { Test for overall effect }\end{array}$ & $\begin{array}{l}=0.19 ; C h \\
\mathrm{t}: Z=2.30\end{array}$ & $\begin{array}{l}\mathrm{i}^{2}=5.8 \mathrm{C} \\
(\mathrm{P}=0 . \mathrm{C}\end{array}$ & $\begin{array}{l}\text { 6, } \mathrm{df}=3 \\
\text { 02) }\end{array}$ & $3(P=0$ & $0.12) ; 1^{2}=$ & $=49 \%$ & 0.01 & $\begin{array}{c}0.1 \\
\text { Favours [Remifentanil] }\end{array}$ & $110 \begin{array}{cc}10 \\
1]\end{array}$ & 100 \\
\hline \multirow[t]{7}{*}{ C } & RPCA vs EA duri & ng labor & analg & jesia & & & & & & & \\
\hline & Study or Subgroup & $\begin{array}{l}\text { Remifer } \\
\text { Events }\end{array}$ & $\begin{array}{l}\text { ntanil } \\
\text { Total }\end{array}$ & $\begin{array}{l}\text { Epidur } \\
\text { Events }\end{array}$ & $\begin{array}{l}\text { ural } \\
\text { Total }\end{array}$ & I Weight & $\begin{array}{c}\text { Risk Ratio } \\
\text { M-H, Random, } 95 \% \mathrm{Cl}\end{array}$ & & $\begin{array}{r}\text { Risk } \\
M-H, \text { Ranc }\end{array}$ & $\begin{array}{l}\text { Ratio } \\
\text { dom, } 95 \% \mathrm{Cl}\end{array}$ & \\
\hline & Freeman 2015 & 35 & 447 & 55 & 347 & $63.2 \%$ & $0.49[0.33,0.74]$ & & -1 & & \\
\hline & Logtenberg 2017 & 9 & 94 & 6 & 76 & $36.8 \%$ & $1.21[0.45,3.26]$ & & & E- & \\
\hline & Total $(95 \% \mathrm{Cl})$ & & 541 & & 423 & $100.0 \%$ & $0.69[0.29,1.61]$ & & & & \\
\hline & Total events & 44 & & 61 & & & & & & & \\
\hline & $\begin{array}{l}\text { Heterogeneity: } \mathrm{Tau}^{2} \\
\text { Test for overall effec }\end{array}$ & $\begin{array}{l}=0.26 ; C h \\
t: Z=0.86\end{array}$ & $\begin{array}{l}\mathrm{i}^{2}=2.7 \\
5(P=0 .\end{array}$ & $\begin{array}{l}3, \mathrm{df}=1 \\
39)\end{array}$ & 1( & 0); 1 & & 0.01 & $\begin{array}{c}0.1 \\
\text { Favours [Remifentanil }\end{array}$ & 11 Favours [Epidural] & 100 \\
\hline
\end{tabular}

Fig. 3 The effects of intravenous remifentanil patient-controlled versus epidural analgesia on intrapartum maternal fever within $1 \mathrm{~h}$ of (a), after 1 $\mathrm{h}$ of (b), and during labor analgesia (c)

\section{Apgar score at $5 \mathrm{~min}$}

The Apgar score at $5 \mathrm{~min}$ was reported in five of the included trials [14-17, 21]. No significant difference was demonstrated between RPCA and EA in the Apgar score $<7$ at $5 \mathrm{~min}$ (risk ratio $1.32[0.58,3.01], P=0.51$, $\left.\mathrm{I}^{2}=37 \%\right)($ Fig. $4 \mathrm{c}$ ).

\section{Discussion}

This systematic review and meta-analysis showed that the present data are insufficient to draw the conclusion that the incidence of intrapartum maternal fever is lower with intravenous RPCA than that with EA. Participants receiving intravenous RPCA experienced satisfaction with pain relief inferior to that of those receiving EA during labor. Meanwhile, respiratory depression occurred in patients receiving intravenous RPCA more frequently than it did in EA patients. There is an equivalent incidence of Apgar scores less than seven at $5 \mathrm{~min}$ between patients receiving intravenous RPCA and those receiving EA.

Regardless of when maternal temperature was measured, the risk ratio of intrapartum maternal fever after receiving intravenous RPCA was far lower than that after receiving
EA. Within $1 \mathrm{~h}$ after pain relief, no maternal fever was observed in two studies $[17,21]$. A previous study had investigated whether patients receiving EA developed pyrexia after only $6 \mathrm{~h}$ of labor [22]. Consistent with these finding by Fusi et al. [22], patients receiving EA with or without fentanyl are at an increased risk of hyperthermia approximately $5 \mathrm{~h}$ after analgesia compared with those receiving only parental opioid analgesia [23]. In addition, no such trend was observed in participants receiving such parental opioids as pethidine [22] or nalbuphine [23]. Obviously, an insufficient duration of measuring maternal temperature might not have allowed for a pyrexia event to be observed in the two trials $[17,21]$.

In response to excluding trials with other comparison groups, there was no significant difference in intrapartum maternal fever between the intravenous RPCA and EA groups. A good explanation is that the sample size was calculated according to the satisfaction with pain relief during labor $[14,15]$. Furthermore, two studies reported that less than $50 \%$ of randomized participants actually received pain relief with RPCA or EA, resulting in a high selection bias. The primary endpoint was 


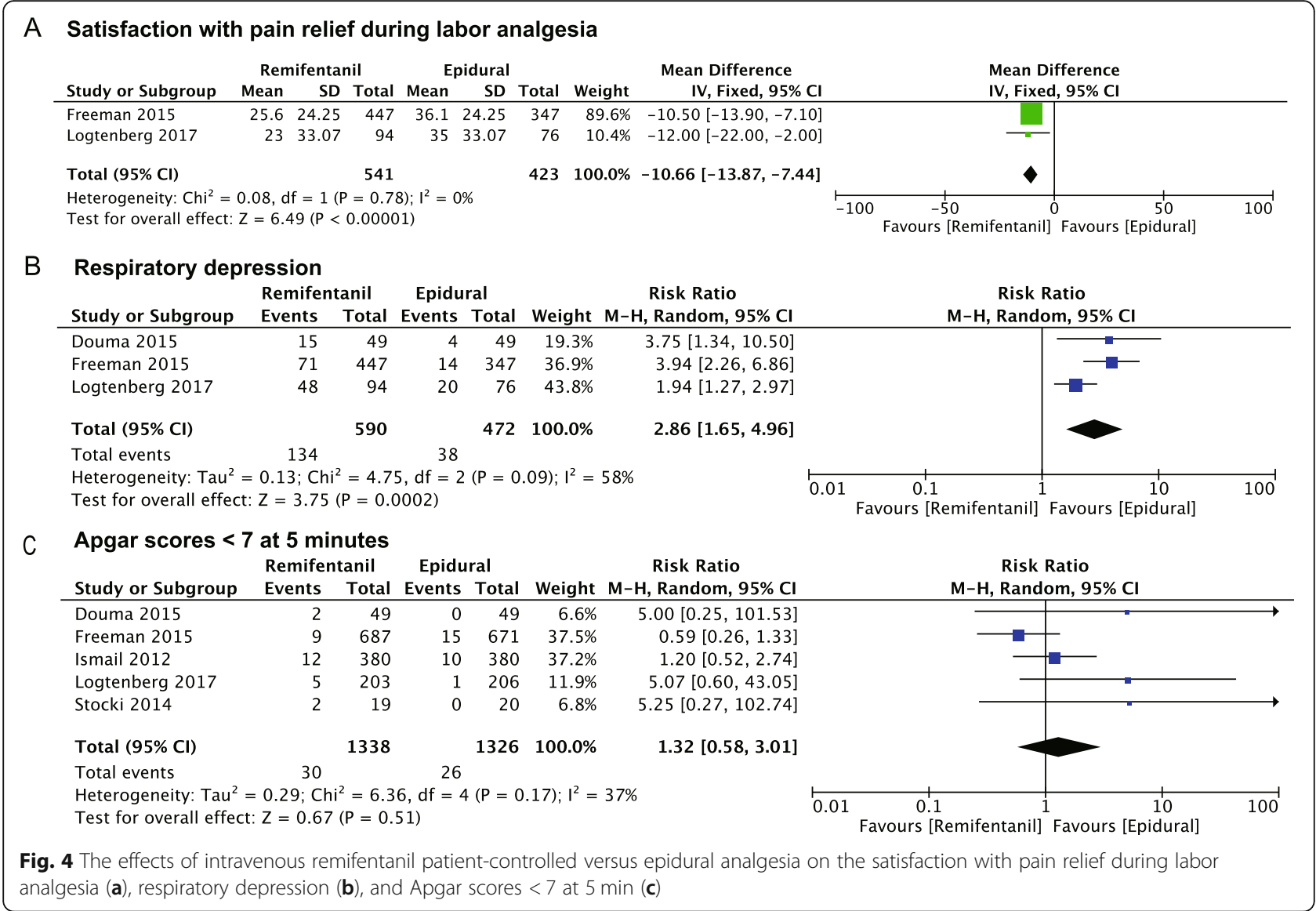

defined as the intrapartum maternal fever within $4 \mathrm{~h}$ in only one included study [16]. Regarding the limitations of such included trials, the current data fail to confirm that RPCA is superior to EA in decreasing the risk of intrapartum maternal fever. Future efforts towards this issue should mainly be focused on providing compelling data based from high-quality trials.

It is well established that the visual analog scale is usually used to assess pain relief. Actually, the intensity of pain is associated with the strength of uterine contractions during labor. The visual analog scale at a single timepoint is difficult to use to evaluate pain relief for the whole labor period, given that patients are not examined during a uterine contraction. The AUC based on a series of visual analog scales was used to compare the satisfaction with pain relief in this study. In contrast to women receiving EA, women receiving intravenous RPCA experienced the worst pain relief during labor, which was in agreement with a Cochrane review [24]. Interestingly, a previous clinical trial has demonstrated that intravenous remifentanil combined with epidural analgesia provides higher satisfaction with labor pain relief than single epidural analgesia [25]. A new multicenter, open-label, randomized controlled trial confirmed that RPCA is superior to pethidine for alleviating labor pain without serious adverse events [13]. Due to genetic polymorphisms, there are differences in not only opioid consumption but also in individual sensitivity to pain $[26,27]$. If the individual genetic polymorphism is identified before administering opioids, intravenous remifentanil analgesia should yield better satisfaction with labor pain relief.

Respiratory depression in mothers and neonates is recognized as the main potential complication of remifentanil analgesia for labor pain. Our analysis demonstrated that patients receiving RPCA are at an increased risk of respiratory depression in comparison with those receiving EA. Respiratory depression was identified using the monitored desaturation. In fact, it is difficult to continuously monitor desaturation during labor. Hence, intravenous RPCA contributes to a much greater workload than EA. Fortunately, there were no significant effects on Apgar scores less than seven at 5 minutes by RPCA or EA. Intravenous RPCA is safe for women during delivery if frequent and careful desaturation monitoring is mandatory.

There are some limitations in this review. First, the direct comparison between RPCA and EA in maternal pyrexia during labor was only performed in one included trial. Second, the sample size of all included trials, except 
one by Douma et al. [16], was calculated according to such primary outcome as the intrapartum maternal fever during labor analgesia. There is no doubt that a high risk of analysis bias was seen among those included trials. Third, due to the different approaches of RPCA and EA, it is still difficult to achieve real blinding of both patients in labor and analgesia managers. A medium to high risk of performance and detection bias was seen in most of the included studies. The endpoint must be affected by the patient preference to avoid an invasive epidural catheter near to the spinal cord. It seems to be feasible to administer intravenous and epidural pumps in the same patient. However, it involves in an extra risk for the invasive epidural procedure in patients randomized to receive intravenous analgesia.

\section{Conclusion}

This systematic review and meta-analysis suggested that there is no solid evidence to illustrate that the risk of intrapartum maternal fever decreases with RPCA in comparison with EA. Intravenous remifentanil analgesia is effective in attenuating labor pain. The increasing incidence of respiratory depression is an obstacle for utilizing intravenous remifentanil analgesia for pain relief during labor.

\section{Supplementary information}

Supplementary information accompanies this paper at https://doi.org/10. 1186/s12884-020-2800-y.

Additional file 1. The risk of bias graph for the individual trials.

Additional file 2. The funnel plot.

Additional file 3. Search strategy.

\section{Abbreviations}

AUC: Area under the curve; EA: Epidural analgesia; ERMF: Epidural-related maternal fever; PRISMA: Preferred Reporting Items for Systematic Reviews and Meta-Analyses; PROSPERO: International Prospective Register of Systematic Reviews; RCTs: Randomized controlled trials; RPCA: Remifentanil patient-controlled analgesia

\section{Authors' contributions}

$G L, W Y, X C, S Z$, and $M Z$ were all involved in the processes of study design, data extraction, and statistical analysis. Guolin Lu wrote the manuscript. WY and XC were responsible for the selection of articles. All authors read and approved the final version of the manuscript.

\section{Funding}

Not applicable.

\section{Availability of data and materials}

All data generated or analyzed during this study are included in this article (and its supplementary files).

\section{Ethics approval and consent to participate}

Not applicable.

\section{Consent for publication}

Not applicable.

\section{Competing interests}

No external funding and no competing interests are declared.
Received: 28 November 2019 Accepted: 10 February 2020

Published online: 12 March 2020

\section{References}

1. Curtin WM, Katzman PJ, Florescue H, Metlay LA, Ural SH. Intrapartum fever, epidural analgesia and histologic chorioamnionitis. J Perinatol. 2015;35(6): 396-400.

2. Greenwell EA, Wyshak G, Ringer SA, Johnson LC, Rivkin MJ, Lieberman E. Intrapartum temperature elevation, epidural use, and adverse outcome in term infants. Pediatrics. 2012;129(2):e447-54.

3. Lieberman E, Cohen A, Lang J, Frigoletto F, Goetzl L. Maternal intrapartum temperature elevation as a risk factor for cesarean delivery and assisted vaginal delivery. Am J Public Health. 1999;89(4):506-10.

4. White A, Olson D, Messacar K. A state-wide assessment of the association between epidural analgesia, maternal fever and neonatal antibiotics in Colorado, 2007-2012. Arch Dis Child Fetal Neonatal Ed. 2017;102(2) F120-F5.

5. Sultan P, David AL, Fernando R, Ackland GL. Inflammation and EpiduralRelated Maternal Fever: Proposed Mechanisms. Anesth Analg. 2016;122(5): 1546-53.

6. Frölich MA, Esame A, Zhang K, Wu J, Owen J. What factors affect intrapartum maternal temperature? A prospective cohort study: maternal intrapartum temperature. Anesthesiology. 2012;117(2):301-8.

7. Del Arroyo AG, Sanchez J, Patel S, Phillips S, Reyes A, Cubillos C, et al. Role of leucocyte caspase-1 activity in epidural-related maternal fever: a single-centre, observational, mechanistic cohort study. Br J Anaesth. 2019;122(1):92-102.

8. Lange EMS, Segal S, Pancaro C, Wong CA, Grobman WA, Russell GB, et al. Association between Intrapartum Magnesium Administration and the Incidence of Maternal Fever: A Retrospective Cross-sectional Study. Anesthesiology. 2017;127(6):942-52.

9. Sharma SK, Rogers BB, Alexander JM, McIntire DD, Leveno KJ. A randomized trial of the effects of antibiotic prophylaxis on epidural-related fever in labor. Anesth Analg. 2014;118(3):604-10.

10. Feng SW, Xu SQ, Ma L, Li CJ, Wang X, Yuan HM, et al. Regular intermittent bolus provides similar incidence of maternal fever compared with continuous infusion during epidural labor analgesia. Saudi Med J. 2014; 35(10):1237-42.

11. Wohlrab P, Boehme S, Kaun C, Wojta J, Spittler A, Saleh L et al. Ropivacaine Activates Multiple Proapoptotic and Inflammatory Signaling Pathways That Might Subsume to Trigger Epidural-Related Maternal Fever. Anesth Analg. 2019 130(2):321-331

12. Hasegawa A, Iwasaka H, Hagiwara S, Hasegawa R, Kudo K, Kusaka J, et al. Remifentanil and glucose suppress inflammation in a rat model of surgical stress. Surg Today. 2011:41(12):1617-21.

13. Wilson MJA, MacArthur C, Hewitt CA, Handley K, Gao F, Beeson L, et al. Intravenous remifentanil patient-controlled analgesia versus intramuscular pethidine for pain relief in labour (RESPITE): an open-label, multicentre, randomised controlled trial. Lancet. 2018;392(10148):662-72.

14. Freeman LM, Bloemenkamp KW, Franssen MT, Papatsonis DN, Hajenius PJ, Hollmann MW, et al. Patient controlled analgesia with remifentanil versus epidural analgesia in labour: randomised multicentre equivalence trial. BMJ. 2015;350:h846.

15. Logtenberg $\mathrm{S}$, Oude Rengerink K, Verhoeven CJ, Freeman LM, van den Akker E, Godfried MB, et al. Labour pain with remifentanil patient-controlled analgesia versus epidural analgesia: a randomised equivalence trial. BJOG. 2017;124(4):652-60.

16. Douma MR, Stienstra R, Middeldorp JM, Arbous MS, Dahan A. Differences in maternal temperature during labour with remifentanil patient-controlled analgesia or epidural analgesia: a randomised controlled trial. Int J Obstet Anesth. 2015;24(4):313-22

17. Stocki D, Matot I, Einav S, Eventov-Friedman S, Ginosar Y, Weiniger CF. A randomized controlled trial of the efficacy and respiratory effects of patientcontrolled intravenous remifentanil analgesia and patient-controlled epidural analgesia in laboring women. Anesth Analg. 2014;118(3):589-97.

18. Lee M, Zhu F, Moodie J, Zhang Z, Cheng D, Martin J. Remifentanil as an alternative to epidural analgesia for vaginal delivery: A meta-analysis of randomized trials. J Clin Anesth. 2017;39:57-63.

19. Liberati A, Altman DG, Tetzlaff J, Mulrow C, Gotzsche PC, loannidis JP, et al. The PRISMA statement for reporting systematic reviews and meta-analyses of studies that evaluate healthcare interventions: explanation and elaboration. BMJ. 2009;339:b2700. 
20. Evron S, Ezri T, Protianov M, Muzikant G, Sadan O, Herman A, et al. The effects of remifentanil or acetaminophen with epidural ropivacaine on body temperature during labor. J Anesth. 2008;22(2):105-11.

21. Ismail MT, Hassanin MZ. Neuraxial analgesia versus intravenous remifentanil for pain relief in early labor in nulliparous women. Arch Gynecol Obstet. 2012;286(6):1375-81.

22. Fusi L, Steer PJ, Maresh MJA, Beard RW. Maternal pyrexia associated with the use of epidural analgesia in labour. Lancet. 1989; 1 (8649):1250-2.

23. Camann WR, Hortvet LA, Hughes N, Bader AM, Datta S. Maternal temperature regulation during extradural analgesia for labour. $\mathrm{Br} J$ Anaesth. 1991;67(5):565-8.

24. Weibel $\mathrm{S}$, Jelting $Y$, Afshari A, Pace NL, Eberhart $L H$, Jokinen J, et al. Patientcontrolled analgesia with remifentanil versus alternative parenteral methods for pain management in labour. Cochrane Database Syst Rev. 2017;4: Cd011989.

25. Tveit TO, Seiler S, Halvorsen A, Rosland JH. Labour analgesia: a randomised, controlled trial comparing intravenous remifentanil and epidural analgesia with ropivacaine and fentanyl. Eur J Anaesthesiol. 2012;29(3):129-36.

26. LV J, Liu F, Feng N, Sun X, Tang J, Xie L, et al. CYP3A4 gene polymorphism is correlated with individual consumption of sufentanil. Acta Anaesthesiol Scand. 2018;62(10):1367-73.

27. Zubieta JK, Heitzeg MM, Smith YR, Bueller JA, Xu K, Xu Y, et al. COMT val158met genotype affects mu-opioid neurotransmitter responses to a pain stressor. Science. 2003;299(5610):1240-3.

\section{Publisher's Note}

Springer Nature remains neutral with regard to jurisdictional claims in published maps and institutional affiliations.

Ready to submit your research? Choose BMC and benefit from:

- fast, convenient online submission

- thorough peer review by experienced researchers in your field

- rapid publication on acceptance

- support for research data, including large and complex data types

- gold Open Access which fosters wider collaboration and increased citations

- maximum visibility for your research: over $100 \mathrm{M}$ website views per year

At $\mathrm{BMC}$, research is always in progress.

Learn more biomedcentral.com/submissions 